\title{
US pressures Japan over imbalance in basic research
}

\section{Washington}

THE little-known US-Japan Science and Technology Agreement may be due for a rise in status. The agreement, a vague umbrella accord first signed in 1980 , has never been the stuff of which headlines are made. But negotiations for its renewal are under way with the US side eager to make the agreement incorporate concrete measures to reverse the flow of science and technology from the United States to Japan.

The agreement, originally signed by President Carter and Prime Minister Ohira, is set to expire on 31 October. To White House science adviser William Graham that seemed to provide a timely opportunity to try to make some changes in the US-Japan relationship. But change is not going to come quickly; the first round of nego-tiations ended on Monday with the dead-line for expiry put back three months in order to give more time for negotiations.

Pressure for change has been building on both sides of the Pacific. In the United States there has been some resentment at the numbers of Japanese researchers who study at top US universities and research institutes and then return home to put their knowledge to work in commercial products. In 1986 there were 323 Japanese researchers at the National Institutes of Health; all had won their places in open competition but many came from biotechnology companies which will one day compete with their opposite numbers in the United States. Particularly galling is that 90 per cent of the visiting Japanese are supported by US government grants.

In return, only a handful of US scientists study in Japan. But that does not mean Japan is content with the situation The obvious weakness of Japanese basic research is an embarrassment and stimulates endless national self-examination but little action. Even the much touted Human Frontiers Programme, intended to put Japan at the helm of a massive international programme of basic research, seems destined to follow Prime Minister Yasuhiro Nakasone into retirement.

In evidence before a congressional hearing on the eve of the negotiations, both Graham and John Negroponte, who is responsible for international scientific affairs at the State Department, stressed that the administration is hoping that Japan will "act aggressively" to find ways to achieve "balance and reciprocity" in basic scientific and technological exchange. Specific proposals have been worked out and were incorporated in a diplomatic note transmitted to Japan in August. The proposals, which remain confidential in their details, are not expected to win ready acceptance from Japan.

"Reciprocity", rather than equality, has become the aim as negotiators recognize the huge differences in the two nations' cultures. The US strength is in basic research, carried out in universities and national laboratories which are open to all. Japanese universities and government institutes support less research. And while in theory they are open - recent reforms have even made it technically possible for foreigners to hold permanent posts in Japanese national universities - it is very hard even for Japanese researchers to move from one laboratory to another. Postdoctoral fellowships, which give some independence to young researchers, are only just being introduced. But more places for US researchers at Japan's research institutes should be negotiable.

Japan's strength in applied research is what the US administration would like to tap most of all. But access to applied research in exchange for the continuing Japanese presence in US basic research laboratories will be difficult to negotiate, however attractive it may seem. Most of Japan's applied research is carried out in company laboratories where the government cannot easily demand change, although it can influence programmes where it provides part of the funds.

Although several witnesses at the congressional hearing clearly felt angered by Japanese exploitation of US research, others saw much of the blame lying in the United States. That 70 per cent of Japan's technology imports have come from the United States is seen by some as symbolic of US failure to capitalize on its own basic research. And the biggest barrier to access to Japanese laboratories may not be the government but the language. There is no evidence that US researchers are being turned away from Japanese laboratories in any numbers. Nevertheless, the US administration view appears to be that as Japan profits from its relationship with the United States it has to find some way to set matters right.

With the next round of negotiations scheduled to take place in Tokyo in December, it is clear that quick results are not expected. But the Japanese side has taken the message that the imbalance in basic research is now an important issue in US-Japan relations. Japan cannot afford to be complacent. Waiting in the wings are those who would like to see all Japanese researchers banned from the US laboratories, or at the very least see part of the US research budget charged to the Japanese government as a condition of their continuing presence. Alun Anderson

\section{Chemistry prize for makers of macromolecules \\ Washington}

This year's Nobel prize in chemistry was almost awarded to Donald O. Cram, a Los Angeles carpet cleaner who happens to have a bachelor's degree in chemistry. The Nobel committee fortunately retrieved its mistake and was able to make the award to Donald J. Cram of the University of California at Los Angeles, JeanMarie Lehn of Louis Pasteur University, Strasbourg, and the Collège de France, Paris, and Charles J.Pedersen, now retired, of the du Pont company in Wilmington, Delaware.

The winners are between them responsible for creating 'supramolecular' or 'guest-host' chemistry, in which the shape of the participating molecules is fundamental to the progress of reactions. Pedersen did much of the early work, and his original goal was to find a way of controlling the action of a vanadium catalyst in a scheme for producing a synthetic rubber. This never came to fruition, but Pedersen discovered in the course of his efforts cyclic molecules crown ethers - which could accommodate in a central position in their structure a metallic ion. Cram and Lehn extended this work, creating crown ethers which attach to amino acids and then more complex molecules which, by joining in a specific way with simple organic molecules such as acetylcholine, mimic the chemical reactions of enzymes.

The experience gained by Lehn and Cram in particular has led to more quantitative detailed understanding of how molecular properties generate selectivity in reactions. For the time being, their work is 'basic research at its most pure', but in the long term there are obvious indications of significance for biochemistry. The selective transport of ions across biological membranes and the mimicking of enzyme chemistry are cited by the Nobel committee as two areas where guest-host chemistry can not only improve understanding but also engender applications, such as the extraction of toxic metals from living organisms.

The three winners have never worked together, and Cram likes to describe them as 'colleague-competitors'. According to Harvey Lubo, a chemist in Cram's department, the research recognized in this year's prize is the result of various different lines of investigation coming together, rather than an outgrowth from a central idea. But the awarding of a Nobel prize is a sign that guest-host chemistry is now a legitimate speciality, with methods and goals of its own.
David Lindley 